\title{
An Effective Supervisory System to Achieve Qualified General Election in Indonesia
}

\author{
Raja Ahab Damanik ${ }^{1}$, Saldi Isra ${ }^{2}$, Yuslim $^{3}$, Suharizal ${ }^{4}$ \\ ${ }^{1}$ Doctoral Degree Student, ${ }^{2}$ Professor, ${ }^{3}$ Senior Lecturer, ${ }^{4}$ Senior Lecturer in Faculty of Law, Andalas University, \\ Padang City, West Sumatra, Indonesia
}

\begin{abstract}
Manipulation in the administration of elections is incompatible with the spirit of democracy. Bawaslu is a determining body for upholding democratic values of elections and must carry out the mandate of the law. The failures in terms of election supervision carried out by Bawaslu in implementing previous election supervision must be evaluated fundamentally so that future election violations can be avoided and reduced. Weak control at the time of voting implies the abuse of a person's voting rights by repeatedly voting, injuring the voting results. An honest and quality election is achieved if all elements of society, especially the parties involved in organizing the election, can maintain their credibility, independence and advance the Nation and the State.
\end{abstract}

Keywords: Supervisory system, general election

\section{Introduction}

Every democratic government organizes general elections (Pemilu) democratically because it is an essential pillar of modern democracy. ${ }^{1}$ Elections under the principle of democracy must implement a transparent mechanism and the precise arrangement of administration. Lance Castle ${ }^{2}$ stated that elections are an inseparable means of the political life of a modern democratic country.

Supervision on the implementation of elections to maintain this principle and ensure that it can exercise its sovereignty must be supervised to comply with its objectives. The implementation of an effective and efficient election is under the provisions contained in Article 22E paragraph (1) of the 1945 Constitution,

\section{Corresponding Author: \\ Raja Ahab Damanik \\ Doctoral Program Candidate in Law, Faculty of Law, Universitas Andalas, Indonesia \\ e-mail: ahabdamanik@gmail.com}

General Elections and Article 2 ( $b$ and 1 ) of Law Number 15 of 2011 (Law No.15 of 2011) concerning Election Administrators, General Elections and Article 2 of Law Number 7 of 2017 (Law No.7 of 2017) concerning general elections for members of parliament (DPR), Regional Representative Council (DPD), Provincial Regional People's Representative Assembly (DPRD) and Regency / Municipal DPRD, to achieve effective and efficient elections based on direct, general principles. Free, confidential, honest, and fair (LUBER and JURDIL) for the sake of creating a credible and quality election; these are the aspirations and hopes of all Indonesian people. The election is a process, a method of voting carried out simultaneously by all the people of a country. ${ }^{3}$ The electoral system is a set of several interrelated elements with one that is contained in the election process carried out by the people of a country. ${ }^{4}$

In developing public governance management characterized by good governance, supervision is an important aspect to maintain government functions. In this context, surveillance becomes as crucial as the implementation of good governance itself. Adequate electoral control covers a broad range of tasks, starting 
with efforts to ensure the fairness of election laws and procedures and ending with monitoring the resolution of objections to election conduct. The monitoring process includes a long process from the pre-election stage to the post-election phase at the election time. The results of this supervision must show the extent to which the matches and incompatibilities are, find the discrepancies that arise, and then find a solution for them to be avoided in the next election. Election monitoring activities are performed in various forms, not only in observation but also in other forms of active accompaniment. Thus, election supervision activities are not limited to direct comment in the field during the campaign or on election day but also include lobbying and mediation activities oriented towards improving the implementation of the next election. ${ }^{5}$

Bawaslu (General election supervisory agency) The general election supervisory body as a determining body for the upholding of the democratic values of elections must be able to carry out the mandate of the law so that what the people want can be realized so that we can achieve honest and quality elections for the progress of the nation and state. The spirit of Bawaslu's presence in the implementation of elections is vital for the realization of democratic elections following the principles of Luber and Jurdil so that we can achieve the credibility and quality of election administration properly following the expectations shared by all the people. Indonesia. So it is not easy to imagine how the election would be credible and quality without supervision. ${ }^{6}$ This institution is an election management body that is permanent and has the authority to oversee the implementation of elections because there is no way to supervise without power (geen ongeautoriseerd toezicht). Considering that this supervisory institution's function is very much needed to uphold democratic values, with authority possessed by this election supervisory institution, we will achieve quality elections' ideals. This institution must have full control. The weakness that Bawaslu has due to the limitations of its duties and powers in overseeing the implementation of elections will ultimately endanger the course of democracy in Indonesia. ${ }^{7}$

Another factor that influences the existence of election supervision activities is credibility. As Stoddart said, projecting a credible impression will pave the way for creating the effect of a surveillance operation. Therefore, it must play an essential role in the decisionmaking process. Credibility is closely related to its nonpartisan attitude because neutrality is a primary factor that develops the credibility of election supervision in the public's eyes so that their voices will be heard. Credibility is ultimately measured by the government's level of trust, election contestants, and the general public in the integrity of election supervision activities and the accuracy of finding and handling problems during implementation by the election supervisory agency.

The impartiality or freedom of political contestants does not mean that Bawaslu should not be associated with political parties. On the other hand, it is essential to liaise with political contestants to explain the organization's goals and guiding principles and what the supervisor's activities will produce. Thus, Bawaslu must be careful in carrying out their supervisory duties; Bawaslu also needs to remind the field supervision work carried out by the Field Supervisory Committee (PPL). ${ }^{8}$

In carrying out the task of supervising the implementation of elections, Bawaslu has the authority to resolve election disputes. ${ }^{9}$ This authority is also confirmed again in a different law that Bawaslu can resolve election disputes. ${ }^{10}$ So that Bawaslu has a firm legal basis to be involved in resolving election disputes. ${ }^{11}$ Apart from its supervisory duties and authority in resolving election disputes, Bawaslu also has another function: prevention. Prevention means making efforts to prevent violations of the implementation of elections as outlined in the Election Law. Although Law No.15 of 2011 does not explain this matter in detail, Bawaslu can formulate its types, forms, and preventive measures to be taken, so that election violations do not occur. ${ }^{12}$

The number of irregularities during the implementation of the election for legislative candidates resulted in a wave of protests. Not a few people were less enthusiastic and already bored with the massive forms of fraud and violations at every stage of the election. ${ }^{13}$ This problem has led to many assumptions in society that think that the government and election administrators are not neutral in carrying out their duties. This problem then gave birth to ideas to continue 
to improve the election law to enhance the quality of elections. Violations and fraud continue to occur and are increasingly complex from time to time; the number of people and election participants who make mistakes makes the role of Bawaslu very important in every stage of the election implementation. Without adequate supervision, it will undoubtedly result in unsatisfactory goals, both for Bawaslu itself as a supervisory institution and for all Indonesian people who expect an increase in welfare from the held elections' results..

\section{Discussion}

\section{Legal Basis for Election Supervision}

The implementation of elections is regulated in CHAPTER VIIB, namely Article 22E of the 1945 Constitution. So with the mandate of the 1945 Constitution, a law related to elections was issued, namely Law Number 7 of 2017 concerning the General Election of members of the DPR, DPD, DPRD, and Law Number 15 of 2011, which regulates election organizers.

Article 22E paragraph (5) of the 1945 Constitution ${ }^{14}$ states that the election organizer is a National Election Commission, permanent and independent, without mentioning an election supervisory institution. However, Article 22E also confirms in paragraph (6) that the law should regulate further provisions regarding general elections. Thus, the existence of an election supervisory institution can be seen in Law no. 15 of 2011 concerning election administrators, namely article 69 paragraph (1), which states that: "Bawaslu, Provincial Bawaslu, Regency / City Election Supervisory Committee (Panwaslu), Sub-district Panwaslu, Field Election Supervisors and Overseas Election Supervisors supervise the Election Implementation" whereas in Law no. 7 of $2017^{15}$ the same thing is also mentioned, namely in article 89 paragraph (1) which states: "Bawaslu supervise the Election.".

The legislative election implementation system adopts a Proportional Election System with an open list of candidates and a multi-member district system. A free proportional system is applied to elect members of the DPR, Provincial DPRD, and Regency / City DPRD. In contrast, the representative district system is involved in elections to elect members of the DPD. ${ }^{16}$ With a proportional system with an open list of candidates, we can overcome the problem of loosening ties between people's representatives and their constituents. On the other hand, it can avoid bias against small parties. ${ }^{17}$. The public is allowed to vote for a political party sign under which there is a list of candidate representatives who will sit in the legislature. Khoirudin assessed that this system represents the characteristics of a balanced (proportional) representation system as well as a district system, so it is termed a proportional system with a free or semi-district candidate list. ${ }^{18}$ This system expects the public to be more interested in participating in the election implementation. Also, with the law's existence, as mentioned above, the public can play a more active role in following and supervising so that election is carried out effectively and efficiently based on direct, general, free, secret, honest and fair. ${ }^{16}$

The various weaknesses that occurred during previous elections and which have never been followed up legally have fostered the desire of different circles of society to improve the elections' quality. People do not think that whoever leads Indonesia remains the same as in previous periods or even worse than the earlier leaders, especially in law enforcement. Election fraud data should not be considered trivial because if the election only considers security, smoothness, and without violence, it forgets the aspects of its implementation process, which are full of fraud. The election is incapable of producing substantially democratic elections but only procedurally democratic elections. ${ }^{19}$

The Election Supervisory Body (Bawaslu) under the law has a vital role in every election implementation. According to article 1 paragraph (16) of Law No.15 of 2011 and also Article 1 paragraph (17) of Law no. 7 of 2017 states that this institution is an election management body in charge of overseeing the implementation of elections throughout the territory of the Unitary State of the Republic of Indonesia, including during the General Election for members of the People's Representative Council (DPR), Regional Representative Council (DPD), and Regional People's Representative Council. (DPRD) or a legislative election.

Bawaslu carries out monitoring activity from the beginning of the preparation until the end of the 
election implementation. Thus, all the activities can realize the expected results from the legislative election implementation process. In consideration of Law No.8 of 2012 states that to have members of the DPR, DPD, and DPRD elections is a means of manifesting people's sovereignty to produce aspirational, quality, and responsible people's representatives based on Pancasila and the 1945 Constitution. So, from the preamble sound, we can conclude that in producing aspirational, quality, and responsible people's representatives, the legislative election implementation process needs supervision. Elections must not take place fraudulently and do not comply with the rules. There is considerable risk if the election is running without supervision. If there is no supervision, this is a violation of the public's sovereign rights. ${ }^{13}$ Due to the large number of contestants involved in the democratic party, this legislative election became a political arena full of fraud and violations.

\section{Parameters of democratic elections}

In the administration of free, honest, and fair elections, there need to be general conditions supporting the electoral process. These general conditions include the following:

1. The regulations do not impose reasonable restrictions on parties and voters..

2. Participants (representing the government, political parties, and others) respect the right to freedom of expression, freedom of association, and freedom to assemble for a period sufficient to allow political parties to organize and campaign to inform the people about the candidate's profile..

3. The government provides guarantees for a ballot to be secret and free from intimidation..

4. The government guarantees the integrity of the voting and counting process.

5. There is no discrimination in the services of political contestants, voter registration requirements and other political rights.

6. Procedures for law enforcement, including legislative, judicial arrangements and procedures that issue notifications, hearings, and challenges that protect against arbitrary or impartial structures and provide practical aid to reducing/limitation of protected rights.

7. Efforts to ensure the integrity and credibility of the electoral process, including providing that there is transparency in the process and that voters understand their rights, choices put forward, and voting procedures practical. $^{5}$

These general conditions imply the need for an aspect of freedom for citizens to determine their voting rights and guarantees of honesty and justice in the process of organizing elections. These three aspects are the core of democratic election parameters; as stated by Austin Ranney that there are at least eight essential characteristics of election administration that can be categorized as free elections, namely: regular elections; meaningful choices; freedom to put forth candidates; freedom to know and discuss the choices; universal adult suffrage; the equal weighting of votes; free registration of choices; accurate counting of choices and reporting of results. ${ }^{20}$ The characteristics of a competitive election are put forward by Morris Janowitz and Dwayne Maverick as follows.

1. The quality of an election depends upon the degree to which competition produces high levels of citizen participation among all social groupings.

2. The quality of an election depends upon the extent to which citizen participation is based on predispositions of high political self- compidence as well as the traditionally emphasized self-interest in the outcome of elections.

3. The quality of an election depends on the extent to which competition stimulates effective political deliberation on the issues and candidates and creates a meaningful basis on which citizens can make their voting decisions.

4. The quality of an election depends upon the extent to which limitations operate including either side from monopolizing or exercising pevasive influence by means of the mass media.

5. The quality of an election depends upon the extent to which the influence exercised by interpersonal 
pressures creates substantially independent of the influence exercised by the mass media. ${ }^{21}$

Based on the various opinions stated above, the quality of the election lies in the presence or absence of the degree of fairness, which includes freedom, honesty, justice, the presence of a competitive nature, and the degree of representation in the electoral system and process. That is, democratic elections require genuine competition between political parties and individual candidates to gain support from all walks of life, maintain the voice of their loyal supporters, win support from independent voters, and even win sympathy/votes from the people. Who in the previous election became a supporter of a rival party. Quality elections require public involvement in all stages. This community involvement must be based on adequate political self-confidence and political self-interest.

\section{Election Supervision Effectiveness Criteria}

Bawaslu, in carrying out its function as supervisor effectively, several aspects support the success of supervisory activities. Timberman argues that the following elements determine the success of election supervision:

a. Mobilization of human, financial, and other resources

b. Communication effectively both internally and with other parties involved in the election.

c. The attitude of non-partisan supervisors includes consistency in upholding the rules of order, a fair (balanced) perspective, and approach. Not involving or working for the contestants.

d. Credibility is measured by the government's level of confidence, contestants, and the general public in the integrity of election supervision activities and the accuracy of the findings of the oversight institution.

e. Coordination with other election management bodies and election observers, including clarity of form, division of tasks, and duration of cooperation. ${ }^{22}$

In line with the above opinion, Legowo argues that the presence of independent supervisors will affect the quality of the election if the institution can minimize the obstacles faced, which include:

1. Technical and financial constraints, consisting of funding difficulties, the level of human resources of its members, and geographic reach

2. Legal and political constraints include lack of knowledge in the field of law, access to data and information as well as clear standard procedures to follow up on the results of monitoring. ${ }^{23}$

Practical election observers cover a broad range of tasks, starting with efforts to ensure the fairness of electoral laws and procedures and ending with oversight of the settlement of objections to elections' conduct. It means that it must also see the effectiveness of election supervision from the scope of its activities during the election administration, which includes:

1. Pre-Voting Stage of the Election;

2. The Voting and Counting Stage of the election results;

3. The post-voting stage of the election results;

Another factor contributing to the effectiveness of election oversight activities is credibility; as Stoddard argues, projecting a credible image will give way to an oversight operation's efficacy and, therefore, must play an essential role in the decision-making process. ${ }^{5}$ Credibility is closely related to its non-partisan attitude because neutrality is a necessary factor that develops the credibility of election supervision in the public's eyes so that their voices will be heard. ${ }^{23}$ Credibility is ultimately measured by the level of trust of the government, contestants, and the general public in the integrity of the election supervisor's activities and the accuracy of the election supervisory agency's findings. ${ }^{22}$

The impartiality or freedom of political contestants does not mean that election oversight bodies must be independent of political parties. On the other hand, it is essential to liaise with political contestants to explain its goals and guiding principles and what the supervisor's activities will produce. ${ }^{22}$ Independent observers' main concern should be protecting the integrity of the electoral process but still not preventing observer members from 
expressing their personal political choices in polling stations' secrecy.

Legowo said that to maintain and improve the quality of election supervision, several factors need to be developed, which include:

a. Election supervisory bodies or institutions must be able to declare their neutrality from various competing political forces.

b. Supervisory bodies or institutions are demanded to consistently maintain their fundamental character as societal institutions (society-initiated institutions). It is necessary to maintain the agency or institution's support base, which is based on community volunteering and develop the agency or institution to become part of the community's life even though the ruling government forms these bodies or institutions.

c. Another factor necessary for this regulatory body or agency is their ability to maintain the continuity of their various activities. Besides being essential to show that this body or institution is alive and well and has a reason to live to improve the quality of elections and political life, this continuity is also necessary to maintain relationships with various social levels. ${ }^{23}$

The three factors above basically indicate that the continuity and development of a supervisory agency or institution and the effectiveness of its supervisory activities depend not only on the ability and reliability of the initiators and administrators but also on community support. The point of election supervision activities is determined by the support and participation of all levels and circles of society.

The Existence and Effectiveness of Election Supervision conducted by Bawaslu on the democratization of Election implementation.

Bawaslu conducts adequate election supervision on the democratization of the implementation of legislative elections, meaning the ability of Bawaslu to supervise legislative elections by conducting observation and assistance activities to prevent and detect violations of democratic values in all stages of election administration.
Effective and efficient election supervision includes observation and assistance in all election administration stages, including the pre-voting stage, the voting and counting stages, and the post-voting stage. Bawaslu's involvement in election administration is directed at the democratization of elections to prevent and detect violations of the values of competition, participation, freedom, justice, and honesty in the electoral process. The involvement of election supervisors in election administration is directed at the electoral process's democratization in the sense that it can prevent violations in election administration. The effect of this supervisory institution's existence does not appear to be direct in improving the quality of the elections, but rather on public awareness of the implementation of elections in particular and politics in general. Legowo said that:

"Election supervisors can become a genuine political education arena, where the people are empowered to be able to exercise their rights and carry out their political responsibilities in elections so that their votes collectively determine who holds positions in government (legislative and executive) which in turn will evaluate policies and other government programs following the aspirations of the people represented. ${ }^{23}$

An election supervisory agency's presence can also make people who are accustomed to cheating think again before committing violations in elections. Election supervisors do not have the authority to impose sanctions or criminal penalties for violations that occur; even cheating can be continued, but the fraud is increasingly challenging to do. The risk is even more significant, primarily if the election supervision report is broadcast nationally.

Election supervision's effectiveness is vital in the democratization of election administration. These monitoring activities offer a political reform process, not through a revolutionary path but an evolutionary political awareness process. Through this process, the socialization of democratic values will take place and be embedded in people's political understanding. It is where the democratization of political life will begin. Marloe argues that an essential element in democratization is building people's trust in elections. It implies the following: 
"if citizens do not feel that they are free to exercise political choices, are adequately informed to do so, and that the election respects their options, the electoral process will not indeed be meaningful. Candidates must feel that they have a fair chance of winning votes so that they are encouraged to participate in the process and to respect the election results. It is also crucial for the community so that they can trust the government in the election results. ${ }^{23}$

As part of the effort to rebuild public confidence in the importance of the legislative election process, especially in elections in the future, Bawaslu can increase public confidence that elections can be held honestly, lawfully, and transparently can even encourage community involvement in the process. These elections. It is reinforced by Marloe's opinion as follows:

"Election monitoring by impartial domestic nongovernmental organizations adds significantly to public confidence in the electoral process and provides excellent citizen participation opportunities in the governance process. $^{23}$ ",

Legowo put forward several points that support the importance of election supervision by an independent supervisory agency. According to him, election supervision that is held independently, in the sense that it is independent of government interference, can support the democratic process because:

First, the independent committee is the real means to enable indonesian citizens to consciously use their political rights and freedom in elections. Second, since the committee is originally society-initiated, and does not emerge from any institution with formal authority, the result of its work will have no legal but moral consequences. And if political power claims to have a moral basis, the result of the committee's work may bring about such moral legitimacy to the political power. Finally, if the result of the committee's work in monitoring the election shows that the election has been justly, fairly, and honestly conducted, whoever wins the election will not only have legal legitimacy but, more importantly, moral legitimacy from the people. This will be the precondition of real political stability. ${ }^{22}$
In other words, consistency, constancy, and accuracy of election supervision activities are prerequisites for improving or enhancing the quality of elections. Election administration truly becomes the essence of democracy. Subsequent election monitoring activities can also provide moral legitimacy for a government formed from the results of elections whose implementation is considered honest and fair. This moral legitimacy is vital as a necessary precondition for realizing political stability in the administration of government.

Supervision and law enforcement in elections are crucial for realizing democratic values based on the principles of direct, general, free, honest, and fair (Luber-Jurdil). Thus, do not let all election stages be carried out, but many violations are tolerated or not carried out by law enforcement for these violations. Of the four irregularities that often occur during the election implementation stage, namely:

1. Administrative violations.

2. Breach of election crime.

3. Election disputes.

4. Disputes over election results, currently, election supervisors only have the authority to resolve election disputes, while other violations are not under their jurisdiction to decide.

Administrative violations must be forwarded to the General Election Commissions (KPU) to be resolved by this commission. Simultaneously, the role of election supervisors is limited to providing recommendations to be followed up by the KPU. Meanwhile, election crimes must be forwarded to the Indonesian National Police (Polri) to be processed to be further submitted to the Prosecutor's Office for the prosecution of violations in the trial process in court so that a court judge decides a legal decision. Meanwhile, disputes over election results are the authority of the Constitutional Court to resolve or determine them.

However, the role of election supervisors is not only termed as a "dispute fixer" or "postman for violation reports" because election supervisors are in the "gateway" position to resolve various reports of violations/election 
disputes. The work of a practical election observer will largely determine the next process. Without the election supervisory function, the KPU will be flooded with reports of violations that are not necessarily accurate. Likewise, police investigators will be overwhelmed by the pile of information on election criminal acts that are not necessarily worthy of being followed up.

The task of resolving disputes is also not easy and trivial. The high political temperature, escalating competition, prone to clashes and conflicts of many interests will make disputes prone to occur and difficult to resolve. The election supervisors must issue a final and binding decision if the deliberative process and consensus and the provision of alternative solutions are not accepted by one or both parties to the dispute. In these conditions, the disputing parties test the authority of the election supervisor.

The public that shows their activities in election supervision is one positive indication of political development because this effort is a step to involve the community by voting and being involved in the process. Furthermore, this community participation will provide opportunities for the growth and development of the involvement towards the substance of democracy. Through election supervision, the process of political education takes place in two directions; the community not only accepts political teachings and theories but is also directly involved (directly involvement), which will become a means of learning through action (learning by doing). The awareness that emerges indirect involvement is a form of political education that is very strategic and has a sizeable sustainable aspect. It means that the supervision and assistance activities carried out by Bawaslu have a large enough effect on the growth of public awareness of the meaning of elections.

This form of voluntary participation can also be interpreted as involvement based on political selfconfidence and political self-interest. Bawaslu's involvement can help support the holding of an honest and fair election. The general public's interest and knowledge about elections are minimal because they see the election experience so far only as a means of legitimacy for the authorities.
Election oversight by Bawaslu can play a role in shaping a general belief that political power can and should be exercised to advance human rights and democracy. The public reinforced this statement that the voter education activities carried out by Bawaslu were sufficiently capable of helping voters better understand their rights and obligations in the election process and encourage public participation in overseeing election administration.

Likewise, the public considers that the supervision carried out by Bawaslu is sufficient to prevent and detect violations that can limit citizens' freedom to make choices. This assessment is based on Bawaslu members' ability to see cases of violations related to bribery and intimidation before the voting day. Even though they are considered capable enough, the public believes that the supervision efforts are still not optimal because, in some cases, election supervisors find it difficult to ask the public to be willing witnesses to report due to witnesses' threats and intimidation. It indicates that there is still a lack of legal guarantees that can protect witnesses so that advocacy efforts by election supervisors often encounter obstacles in handling cases of this kind of intimidation. Bawaslu carried out election supervision considered to have had a good effect on the election administration's democratization. However, this assessment is adequate to interpret that there are still obstacles in implementing surveillance to maximize the result.

\section{Conclusion}

The election supervision system still needs improvement effectively and efficiently to be adequately implemented and becomes one of the instruments in realizing the quality and democratic elections. Progress of the election supervision system includes:

They are improving regulations of giving authority to Bawaslu to impose sanctions on election participants who commit violations in the general election.

Strengthening the existence and credibility of election supervisors.

The presence of special powers given to provide recommendations to eligible participants. Political parties that are honest and have never 
committed violations during the election administration to participate in the next election without re-verification as election participants. The election supervision system from year to year will continue to operate in place, or it may even be more complicated because the level of violations that have occurred is increasing so that the implementation of elections will not produce quality and democratic elections.

Ethical Clearance: This research was ethically approved by Faculty of Law, Universitas Andalas, Padang, West Sumatra, Indonesia

Funding: None

\section{Conflict of Interests: None}

\section{References}

1. Ashiddiqie J. Menegakkan Etika Penyelenggara Pemilu. Jakarta: Rajawali Press; 2013.

2. Castle L. Pemilu 2004 dalam Konteks Komparatif dan Historis. Yogyakarta: Pustaka Pelajar; 2004.

3. Purwadarminta WJS. Pusat Bahasa Departemen Pendidikan Nasional, Kamus Besar Bahasa Indonesia. Ketiga. Jakarta; 2011.

4. Fahmi K. Pemilihan Umum dan Kedaulatan Rakyat. Jakarta: Rajawali Pers, PT.Raja Grafindo Persada; 2011.

5. Stoddard. Partisipasi dan Partai Politik- Indonesia Menuju pada Demokrasi. Jakarta: Pustaka Utama Grafiti; 1995.

6. Isra S. Membangun Demokrasi Membongkar Korupsi, Suatu kumpulan Wawancara,. Jakarta: Murai Kencana, PT. Raja Grafindo Persada; 2010.

7. Firmanzah. Persaingan, Legitimasi Kekuasaan dan Marketing Politik: Pembelajaran Politik Pemilu 2009. Pertama. Jakarta: Yayasan Pustaka Obor Indonesia; 2010.

8. Wijardjo B. Suatu refleksi untuk perbaikan penyelenggaraan pemilu. Jakarta: Konsorsium Reformasi hukum Nasional bekerjasama dengan yayasan TIFA; 2008.

9. Pemerintah Republik Indonesia. Undang-Undang Republik Indonesia Nomor 15 Tahun 2011 [Internet]. 15 Indonesia; 2014. Available from: https://www.dpr.go.id/dokjdih/document/uu/ UU_2011_15.pdf
10. Pemerintah Republik Indonesia. UU No.8 Tahun 2012 Tentang Pemilu anggota DPR, DPD, DPRD. Indonesia; 2012.

11. Harun R. Penyelesaian Perselisihan Hasil Pemilihan Umum di Indonesia. Pascasarjana Universitas Andalas; 2016.

12. Supriyanto D. Penguatan Bawaslu: Optimalisasi Posisi, Organisasi, dan Fungsi Dalam Pemilu 2014. Jakarta: Perludem;

13. Sardini NH. Restorasi Penyelenggaraan Pemilu di Indonesia. Yogyakarta: Fajar media Press; 2011.

14. Pemerintah Republik Indonesia. J.D.I.H. - Undang Undang Dasar 1945 - Dewan Perwakilan Rakyat [Internet]. [cited 2021 May 21]. Available from: https://www.dpr.go.id/jdih/uu1945

15. Pemerintah Republik Indonesia. Undang-Undang Republik Indonesia Nomor 7 Tahun 2017 Tentang Pemilihan Umum [Internet]. 2017 p. 1-414. Available from: www.peraturan.go.id

16. Pemerintah Republik Indonesia. UU No.8 Tahun 2012 Tentang Pemilu anggota DPR, DPD, DPRD. Indonesia; 2012.

17. Budihardjo M. Dasar-Dasar Ilmu Politik. Jakarta: PT. Gramedia Pustaka Utama; 2008.

18. Koirudin. Profil Pemilu 2004, Evaluasi Pelaksanaan, Hasil dan Perubahan Peta Politik Nasional Pasca Pemilu Legislatif 2004. Yogyakarta: Pustaka Pelajar; 2004.

19. Rikwanto A. Hukum Partai Politik dan Hukum Pemilu di Indonesia. Yogyakarta: Thafa Media; 2016.

20. Ranney A. The Governing Of Men. New York: Rinehart and Winston, Inc; 1990.

21. Eulau H. Ilmu Politik. Jakarta: Gramedia Pustaka Utama; 1986.

22. Timberman D. Election and Politics In Indonesia. University of Victoria; 1997.

23. Legowo L., Kristiadi J, Harjanto NTB. Pemilihan Umum 1997: Perkiraan, Harapan dan Evaluasi | OPAC Integrasi | Online Public Access Catalog | Universitas Gadjah Mada [Internet]. 1997 [cited 2021 May 21]. Available from: http://opac.lib. ugm.ac.id/index.php?mod=book_detail\&sub= Book Detail\&act $=$ view\&typ $=$ htmlext\&buku $\mathrm{id}=805256 \&$ obyek_id $=1$ 